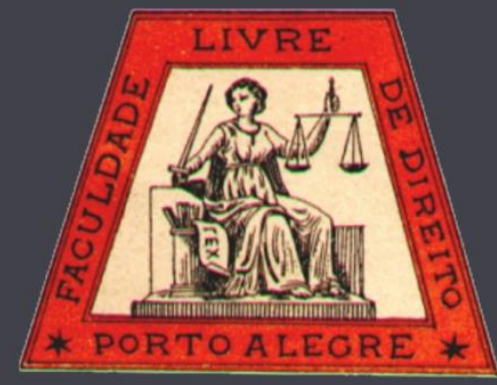

\title{
A teoria da separação dos poderes e a supremocracia: o Supremo Tribunal Federal na Constituição cidadã
}

Theory of separation of powers and supremecracy: Federal Supreme Court in the citizen Constitution

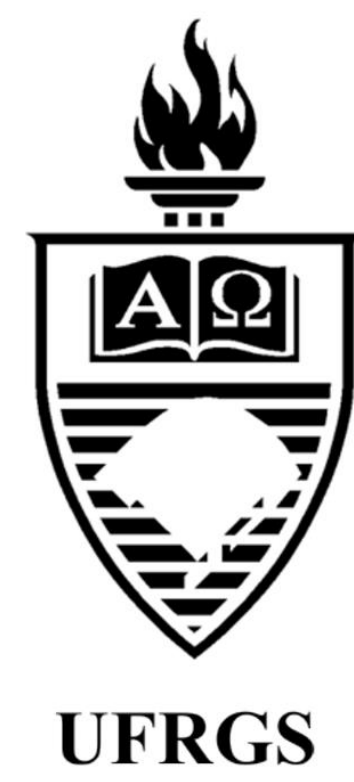

Ana Larissa da Silva Brasil Universidade Regional do Cariri

\section{Robson Gomes}

Universidade Regional do Cariri 


\title{
A teoria da separação dos poderes e a supremocracia: o Supremo Tribunal Federal na Constituição cidadã
}

\author{
Theory of separation of powers and supremecracy: Supreme Federal Court in the citizen \\ Constitution
}

Ana Larissa da Silva Brasil*

Robson Gomes**

\begin{abstract}
REFERÊNCIA
BRASIL, Ana Larissa da Silva; GOMES, Robson. A teoria da separação dos poderes e a supremocracia: o Supremo Tribunal Federal na Constituição cidadã. Revista da Faculdade de Direito da UFRGS, Porto Alegre, n. 34, p. 99-117, ago. 2016.
\end{abstract}

\section{RESUMO}

Este trabalho intui anotar as conceituações acerca do poder, sendo este um dos elementos essenciais de estruturação do Estado e, nesse sentido, um instrumento de governabilidade. Ver-se-á, pois, o posicionamento doutrinário dos maiores constitucionalistas pátrios sobre as principais responsabilidades estatais para alcançar a paz social. Nesse diapasão, será estudada a Teoria da Separação dos Poderes, incluindo um pequeno escorço histórico da Antiguidade até os tempos modernos, nos quais foi aperfeiçoada pela indelével obra de Montesquieu, Do Espírito das Leis. Além disso, ao se visualizar as estruturas dos órgãos das funções estatais (executiva, legislativa e judiciária), averiguar-se-ão os principais delineamentos da Supremocracia, a qual supostamente significa a intromissão do Supremo Tribunal Federal nos assuntos da alçada do Poder Legislativo. Este estudo propõe-se, também, a expor as mazelas do Poder Legislativo, configuradas por sua inércia. Por fim, pretende-se dissecar alguns instrumentos de atuação do Supremo Tribunal Federal, como as súmulas vinculantes e o Controle de Constitucionalidade, de modo a legitimar a sua conduta no cenário nacional.

\section{PALAVRAS-CHAVE}

Supremo Tribunal Federal. Separação dos Poderes. Congresso Nacional. Competência constitucional.

\begin{abstract}
This work intuits to note the conceptions of power, which is one of the essential elements of the state structure and, in this sense, a governance tool. It will be made clear, therefore, the doctrinal position of the main Brazilian constitutionalists on the main state responsibilities to achieve social peace. In this vein, it will be studied the Theory of Separation of Powers, including a brief historical foreshortening from antiquity to modern times, where it was perfected by indelible work of Montesquieu, The Spirit of the Laws. Besides, when viewing the structures of the organs of state functions (executive, legislative, and judicial), it shall be ascertained the main guidelines of supremecracy, which supposedly means the intrusion of the Supreme Federal Court in matters of Legislative competence. This study aims also to expose the weaknesses of the legislature, set by its inertia. Finally, we intend to dissect some instruments of action of the Supreme Court, such as the binding precedents and the judicial review, in order to legitimize its conduct on the national scene.
\end{abstract}

\section{KEYWORDS}

Supreme Federal Court. Separation of Powers. Parliament. Constitutional competence.

\section{SUMÁRIO}

Introdução. 1. A teoria da separação dos poderes. 1.1 O poder e o Estado. 1.2 Origem histórica da Teoria da Separação dos Poderes. 1.3 A impropriedade do termo "tripartição do poder". 2. Supremocracia. 3. Alguns instrumentos de atuação do Supremo Tribunal Federal x Supremocracia. 3.1 As súmulas vinculantes. 3.1.1 Previsão constitucional e

\footnotetext{
* Professora substituta na Universidade Regional do Cariri - URCA. Especialista em Direito do Trabalho e Previdenciário (Faculdade Paraíso do Ceará - FAP-CE, 2016). Graduada em Direito (Universidade Regional do Cariri - URCA, 2011).

${ }^{* *}$ Graduando em Direito (Universidade Regional do Cariri - URCA).
} 
legal. 3.2 O controle de constitucionalidade e a união homoafetiva. 3.2.1 O controle de constitucionalidade. 3.2.2 A união homoafetiva pelo Supremo Tribunal Federal. Conclusão. Referências.

\section{INTRODUÇÃO}

O trabalho em questão aborda sobre a Supremocracia, que é um fenômeno existente no Brasil e que tem consequências nas competências institucionais de cada Poder.

A Supremocracia resulta de uma escolha procedida pelo poder constituinte quando optou por uma Constituição ampla, cidadã, com muitos detalhes e essencialmente principiológica. Além disso, resulta da maneira escolhida para realizar o controle de constitucionalidade das normas e da presença marcante do constitucionalismo entre os demais ramos do Direito.

Um dos motivos pelos quais se fala em Supremocracia é a ambição do constituinte de 1988, que buscou legislar a respeito de diversos âmbitos, quais sejam, sociais, econômicos e de outras ordens. Sendo assim, qualquer assunto que venha a ser tratado no parlamento, pode acabar sendo submetido à apreciação do Supremo, devido à constitucionalização do Direito.

Dentre os reflexos que a Supremocracia vem trazendo ao sistema político brasileiro, pode-se observar que, por vezes, a população tem mais confiança na Corte Suprema do que em seus representantes políticos. Isso ocorre porque a população encontra nos julgamentos do Supremo a esperança de promover direitos e garantias, ocupando um espaço de atuação que deveria ser realizado por aqueles que o povo, legitimamente, colocou no poder para tomar as rédeas do país.

Sendo assim, esse fenômeno será analisado à luz da Teoria de Separação dos Poderes, tendo em vista que houve o aumento do papel do Supremo na resolução de temas cada vez mais políticos, que deveriam ser abordados em outras esferas de Poder, ou seja, no Poder Legislativo e no Poder Executivo.

\section{A TEORIA DA SEPARAÇÃO DOS PODERES}

\subsection{O poder e o Estado}

A Teoria da Separação dos Poderes encontra subterfúgio na existência do Estado, o qual, após colher parcelas singelas de liberdade de cada indivíduo do ambiente social, responsabiliza-se pela estruturação da sociedade e, sobretudo, pelo bem-estar dessa coletividade. Nesse passo, dá-se a um ente um feixe de deveres e prerrogativas para aplicar, ao caso concreto, normas orientadoras da vivência comunitária. Tem-se o poder do Estado que, sobrepujando os interesses isoladamente considerados, prestigiará a vontade de todos.

Ao lado de dois outros elementos intrínsecos ao Estado (povo e território), o poder, segundo pensamento do eminente Paulo Bonavides (2000), é a energia básica que anima a existência de uma comunidade humana num determinado território, conservando-a unida, coesa e solidária. Assim, dois aspectos se entrelaçam ao poder: a competência e a força. A primeira pode ser compreendida, conforme Bonavides (2000), como a legitimidade oriunda do consentimento.

Explica Bonavides (2000) que, quando o poder se apoiar unicamente na força, e a sociedade, na qual ele é exercido, exterioriza o aspecto coercitivo e o emprego de meios violentos para impor a obediência, não importando sua aparente solidez ou estabilidade, ter-se-á um poder de fato. Por outro lado, todavia, se o poder se solidificar menos na força 
do que na competência, menos na coerção do que no consentimento, estar-se-á diante do poder de direito.

Desse modo, o poder pode ser chancelado sob a égide de duas facetas, quais sejam, uma orientada pela imposição de normas pelo Estado com ares de violência, e uma outra calcada no poder consentido pelos destinatários dos mandamentos normativos. Na segunda situação, compreende-se cristalinamente a legitimação popular, o que é curial nos Estados ditos democráticos. Por isso, pleitear uma democracia para a estruturação da sociedade é aquiescer ao poder de direito, o qual se esbarra na própria prerrogativa de controle por meio da inovação jurídica.

Por esses motivos, é possível vislumbrar solarmente a íntima relação que há entre o Estado e o poder, na medida em que este é o instrumento de governabilidade daquele, tendo por fim a paz socialmente alargada. Nessa baila, encontram-se os ensinamentos de José Afonso da Silva (2014):

O poder é fenômeno sócio-cultural. Quer isso dizer que é fato da vida social. Pertencer a grupo social é reconhecer que ele pode exigir certos atos, uma conduta conforme com os fins perseguidos; é admitir que pode nos impor certos esforços custosos, certos sacrifícios; que pode fixar, aos nossos desejos, certos limites e prescrever, às nossas atividades, certas formas. Tal é o poder que se pode definir como uma energia capaz de coordenar e impor decisões visando à realização de determinados fins. O Estado, como grupo social máximo e total, tem também o seu poder, que é o poder politico ou poder estatal. A sociedade estatal, também chamada sociedade civil, compreende uma multiplicidade de grupos sociais diferenciados e indivíduos, aos quais o poder político tem que coordenar e impor regras e limites em função dos fins globais que ao Estado cumpre realizar (p. 108109).

José Afonso da Silva (2014) lucidamente conceitua o poder como uma imposição justificada de sacrifícios, vez que o Estado deve voltar-se ao cumprimento dos fins já aqui explanados, e não como uma exigência da realização das normas desmedidamente violento. Diante, portanto, das obrigações estatais de coordenação, pode-se afirmar que o poder político é superior a todos os outros poderes sociais. Nesse ínterim, o poder estatal reconhece, rege e domina esses poderes sociais, visando a ordenar as relações entre os grupos e os indivíduos entre si e reciprocamente, de maneira a manter um mínimo de ordem e estimular um máximo de progresso à vista do bem comum.

A essa superioridade do poder político dáse o nome de soberania. Com a maestria que lhe é intrínseca, disserta José Afonso da Silva (2014) que a soberania deve ser analisada sob dois planos não excludentes, mas complementares entre si. $\mathrm{O}$ primeiro é a independência em confronto com todos os poderes exteriores à sociedade estatal (soberania externa); já o segundo plano é a supremacia sobre todos os poderes sociais interiores à mesma sociedade estatal (soberania interna).

Enfim, corroborando as argumentações enveredadas em direção à mantença da ordem pelo Estado, Darcy Azambuja (2000) defende que a forma política da sociedade, o próprio Estado, mais do que qualquer outra, é essencialmente ordem e hierarquia, porque englobando inúmeras sociedades, tem de conciliar-lhes a atividade e disciplinar a dos indivíduos que as compõem. Nesse diapasão, a ordem estatal é, a um só tempo, natural e artificial. Natural porque corresponde à necessidade do homem de viver em sociedade, e artificial, porque as sociedades não poderiam subsistir sem a intervenção da inteligência do homem.

\subsection{Origem histórica da Teoria da Separação dos Poderes}

Para melhor compreender a fundamentação da Teoria da Separação dos Poderes, é necessário 
valer-se dos recursos históricos. A priori é indispensável ventilar que o princípio da separação dos poderes, de tamanha magnitude no cenário da Teoria Geral do Estado, a qual se funda na existência do ente estatal, não começa com os escritos de Montesquieu, que o empregou como técnica de salvaguarda da liberdade. Todavia, já pode ser sentido em precursores da Antiguidade e da Idade Média.

Platão (2004), conforme se infere de sua obra República, é o primeiro a idealizar a concepção de uma divisão das funções estatais, com o intuito de desconcentrar o poder. Aludida ideia se clareia quando Platão (2004) propõe uma divisão social de atividades, cabendo aos guerreiros a proteção das cidades; aos magistrados, o governo; e aos mercadores, a produção e comercialização dos bens de consumo. Assim, levanta-se a corrente doutrinária na qual o princípio é o equilíbrio, devendo proporcionar uma organização política formada por partes, surgindo a diretriz que o todo precede as partes.

Contudo, inobstante tenha lançado as primeiras indagações a respeito da Teoria dos Poderes, Platão (2004) não apresentou contornos específicos para completar e sistematizar essa concepção, uma tarefa que ficou aos seus sucessores. Assim, em seguida, conforme Paulo Bonavides (2000), distinguira Aristóteles a assembleia-geral, o corpo de magistrados e o corpo judiciário; Marsílio de Pádua no Defensor Pacis já percebera a natureza das distintas funções estatais e, por fim, a Escola de Direito Natural e das Gentes, com Grotius, Wolf e Puffendorf.

Todavia, Darcy Azambuja (2000) ressalta que Aristóteles, se discriminou os órgãos, confundiu as funções, tendo em vista que deu à assembleia o conjunto de todas as atribuições, sendo os dois outros órgãos simples delegações suas, sem atribuições bem definidas. Por fim, lembra a autora que depois do filósofo grego, a doutrina da "divisão" dos poderes permaneceu longos séculos sem pontuações dos escritores.

Sendo novamente trazida à colação, Locke, segundo Darcy Azambuja (2000), foi o primeiro escritor que realmente elaborou uma teoria da "divisão" dos poderes. Inspirado na Constituição Inglesa, diz Locke (1998), em seus Ensaios, que é necessário que as funções do Estado sejam exercidas por órgãos diferentes. Nesse caso, o direito de determinar a forma como se deve empregar o poder público, para proteger a comunidade e seus membros cabe ao Poder Legislativo. Por outro lado, com base no entendimento de Locke (1998), dada a fragilidade humana, haveria a grande possibilidade de abuso do poder se as mesmas pessoas que fazem as leis, devessem executá-las.

Locke, menos afamado que Montesquieu, é quase tão moderno quanto este, no tocante à separação de poderes. Assinala o pensador inglês a distinção entre os três poderes - executivo, legislativo e judiciário - e reporta-se também a um quarto poder: a prerrogativa. Ao fazê-lo, seu pensamento é mais autenticamente vinculado à Constituição inglesa do que o do autor de Do Espírito das Leis. A prerrogativa, como poder estatal, compete ao príncipe, que terá também a atribuição de promover o bem comum onde a lei for omissa ou lacunosa (BONAVIDES, 2000, p. 173).

É indubitável, porém, que, consoante ensina Azambuja (2000), coube ao jurista e filósofo francês Charles de Sécondat, Barão de Montesquieu, elaborar a teoria completa da divisão das funções estatais, bem como difundila por toda a Europa. Assim, em sua obra-prima Do Espírito das Leis, Montesquieu (2007) propõe em cada Estado três sortes de poderes: o poder legislativo, o poder executivo (poder executivo das coisas que dependem do direito das gentes, segundo sua terminologia) e o poder judiciário (poder executivo das coisas que dependem do direito civil). A cada um desses poderes correspondem, segundo o pensador francês, determinadas funções. 
Paulo Bonavides (2000) enumerando e explicitando cada poder, discorre que por meio do poder legislativo fazem-se leis para sempre ou para determinada época, bem como se aperfeiçoam ou ab-rogam as que já se acham feitas. Já com o poder executivo, ocupa-se o príncipe ou magistrado (os termos são de Montesquieu) da paz e da guerra, envia e recebe embaixadores, estabelece a segurança e previne as invasões. O terceiro poder - o judiciário dá ao príncipe ou magistrado a faculdade de punir os crimes ou julgar os dissídios da ordem civil.

Não é de se olvidar, pois, que a grande reflexão trazida por Montesquieu (2007) está alicerçada na prerrogativa da liberdade, ou mais ainda, no justo receio de restringi-la arbitrariamente, dado o momento perpassado pela França com o Absolutismo Monárquico. Tanto assim que o século XVII se reveste da justificação, propagação e consolidação da doutrina da soberania. Esta doutrina extraiu-se de uma imposição casuísta do poder - o poder do monarca, gradativamente edificado $\mathrm{e}$ ampliado, como absoluto e supremo. Nas palavras de Montesquieu:

\begin{abstract}
A liberdade política somente existe nos governos moderados. Mas nem sempre ela existe nos governos moderados. Só existe quando não se abusa do poder, mas é uma experiência eterna que todo homem que detém o poder é levado a dele abusar: e vai até onde encontra limites. Quem o diria? A própria virtude precisa de limites. Para que não se abuse do poder é necessário que pela disposição das coisas o poder limite o poder (2007, p. 166-167).
\end{abstract}

Enfim, a teoria de Montesquieu, pontua Azambuja (2000), teve extraordinária repercussão na filosofia política e nas Constituições escritas que se promulgaram nos fins do século XVIII, tornando-se um dogma na ciência constitucional. Uma das adoções célebres da "separação" dos poderes ocorreu com a Constituição Federal americana de 1787, que, inobstante não cite sequer uma vez a aludida teoria, tornar-se-ia ininteligível esse documento dos Estados Unidos caso se omita a discussão tripartite dos poderes.

Bonavides (2000) explana que o lugar mais alto atingido pela Teoria da Separação dos Poderes, todavia, deu-se com as Constituições francesas inspiradas pelas máximas do Liberalismo. Com efeito, conforme o art. $16 \mathrm{da}$ Constituição Francesa de 03 de setembro de 1791, na parte relativa à Declaração dos Direitos do Homem e do Cidadão, "toda sociedade na qual não esteja assegurada a garantia dos direitos do homem nem determinada a separação de poderes, não possui constituição".

\subsection{A impropriedade do termo "tripartição do poder"}

Após o escorço histórico delineado acima, é salutar alertar para a impropriedade do termo "tripartição" do poder, vez que, quando se navega pelo sistema principiológico da Teoria da Separação dos Poderes, nota-se, na verdade, uma divisão das funções do poder estatal. José Afonso da Silva (2014) auxilia essa compreensão ao caracterizar o poder político como uno, indivisível e indelegável.

Assim, o Estado, carecedor de uma vontade real e própria, manifesta-se por órgãos supremos (constitucionais) ou dependentes (administrativos). Àqueles, chamados de governo, incumbem o exercício do poder político; já os últimos estão no plano hierarquicamente inferior, compondo a Administração Pública. O governo, seguindo esse diapasão, conceitualmente é o conjunto de órgãos mediante os quais a vontade do Estado é formulada, expressada e realizada. Arremata-se, pois, que a manifestação estatal se dá por funções, quais sejam, legislativa, executiva e jurisdicional. Ainda conforme José Afonso da Silva: 
A função legislativa consiste na edição de regras gerais, abstratas, impessoais e inovadoras da ordem jurídica, denominadas leis. A função executiva resolve os problemas concretos e individualizados, de acordo com as leis; não se limita à simples execução das leis, como às vezes se diz; comportam prerrogativas, e nela entram todos os atos e fatos jurídicos que não tenham caráter geral e impessoal; por isso, é cabível dizer que a função executiva se distingue em função de governo, com atribuições políticas, colegislativas e de decisão, e função administrativa com suas três missões básicas: intervenção, fomento e serviço público. A função jurisdicional tem por objeto aplicar o direito aos casos concretos a fim de dirimir conflitos de interesse (2014, p. 110).

$\mathrm{Na}$ realidade, perceptível é notar a distinção das funções exercidas pelo poder estatal, e não propriamente uma divisão da estrutura do poder. A distinção se respalda, fundamentalmente, pelo singelo motivo do controle do poder pelo poder, ou adaptando para a sistemática mais escorreita, os freios impostos por uma função à outra. Por isso, a necessidade de desmembrar não só as atividades estatais, mas, sobretudo, democratizar o exercício do poder.

\section{SUPREMOCRACIA}

Nos últimos anos, notícias em geral, sobre esportes, economia, política, têm estampado as manchetes de grandes jornais e as mídias sociais, os julgamentos realizados pelo Supremo Tribunal Federal vêm ocupando lugar de destaque nesses meios de comunicação. Seja pelos debates acalorados, ou, simplesmente, pelas demandas a ele destinadas, em sua maioria, de cunho político. Esse estaque aproximou a população, sendo cada vez mais interessante entender como funciona e quem compõe a Corte, afinal, suas decisões são de importância nacional.

A Constituição de 1988 proporcionou uma atuação mais ampla ao tribunal, visto que as constituições anteriores anulavam e/ou limitavam a sua efetiva participação ao interpretar a Constituição, bem como aplicar princípios e ponderação de valores. Sendo assim, a atividade jurisdicional por parte da Suprema Corte era tímida e de pouca efetividade (VIEIRA, 2008).

A estrutura e composição do Tribunal foram mantidas pela Magna Carta, porém, as mudanças ocorridas entre democracia e o constitucionalismo, elencados no texto constitucional, dedicaram ao Supremo Tribunal Federal novas e complexas atribuições. Por exemplo, a apreciação da constitucionalidade do Imposto Provisório sobre Movimentação Financeira - IPMF, criado por meio da Emenda $n^{\circ} 3$ de $1^{\circ}$ de março de 1993 (VIEIRA, 2004).

$\mathrm{Na}$ atual Carta Magna, depreende-se a preocupação com a garantia de uma nação mais democrática e dotada de direitos fundamentais. Desta feita, o Supremo Tribunal Federal tem atuado de forma mais ativa e incisiva, não somente nos casos de controle de constitucionalidade das normas, mas, principalmente, em questões políticas, sendo estas o motivo para tantos holofotes e críticas aos limites de sua atuação.

Desta forma, a Constituição de 1988 trouxe uma série de transformações para o Supremo que resultaram em uma mudança dúbia, como bem pontua Verissimo (2008, p. 410, grifo do autor):

\footnotetext{
Por um lado, colocou o STF em uma posição de absoluto destaque na política nacional, transformando-o em um órgão que passou, pouco a pouco, a agir declaradamente como uma das mais importantes instâncias políticas da nação. Por outro lado, soterrou essa mesma corte debaixo de uma avalanche de processos, obrigando-a a conciliar esse seu papel político, de instância de revisão e segundo turno da política representativa, com um papel bem mais "rotineiro" de prestador de serviços forenses, de "terceira instância" na estrutura judiciária tradicional de solução de disputas individuais.
}

Parte da doutrina fala em um movimento 
chamado de judicialização, esta resulta da maior participação do Poder Judiciário ao decidir questões de repercussão nacional e política, estas que deveriam ser analisadas pelas instâncias políticas, isto é, pelo Poder Legislativo ou Poder Executivo.

Esse fenômeno ocorre pelo fato de, nos últimos anos, o judiciário ter deixado seu patamar de órgão técnico-especializado e ter se transformado em um órgão capaz de atuar de forma política, fazendo valer a Constituição Federal e as leis que entrem em confronto com outros Poderes. A constitucionalização trouxe para a Constituição muitas matérias dantes apreciadas pelo processo político e pelas leis ordinárias. (BARROSO, 2008).

A judicialização decorre, portanto, do novo papel constitucional assumido pela Corte, não sendo um resultado de mudança ideológica, metodológica ou de outra ordem por parte do próprio Supremo.

Outro fenômeno que envolve a atuação do Supremo Tribunal Federal é o chamado ativismo judicial, tão debatido nas universidades e na mídia. Sua conceituação difere da judicialização, apesar das semelhanças. Por ativismo, entendese a possibilidade de ampliar a interpretação constitucional conforme escolha do Tribunal. "A ideia de ativismo judicial está associada a uma participação mais ampla e intensa do Judiciário na concretização dos valores e fins constitucionais, com maior interferência no espaço de atuação dos outros dois Poderes" (BARROSO, 2008).

A crítica feita aos modelos acima citados se coaduna na preocupação com os riscos à legitimidade, a politização indevida da justiça e os limites da capacidade institucional do Judiciário. Assim, os membros do Poder Judiciário não são eleitos pelo povo, porém, desempenham um poder político de destaque, inclusive invalidando atos dos outros Poderes. Portanto, a Suprema Corte possui legitimidade para atuar como um fórum de princípios, velando pela democracia e pelos direitos fundamentais (BARROSO, 2008).

Quanto à politização indevida da justiça, o mesmo autor (2008, grifo do autor) faz a seguinte crítica:

\begin{abstract}
Direito é política no sentido de que (i) sua criação é produto da vontade da maioria, que se manifesta na Constituição e nas leis; (ii) sua aplicação não é dissociada da realidade política, dos efeitos que produz no meio social e dos sentimentos e expectativas dos cidadãos; (iii) juízes não são seres sem memória e sem desejos, libertos do próprio inconsciente e de qualquer ideologia e, consequentemente, sua subjetividade há de interferir com os juízos de valor que formula. [...] juízes não podem ser populistas e, em certos casos, terão de atuar de modo contramajoritário. A conservação e a promoção dos direitos fundamentais, mesmo contra a vontade das maiorias políticas, é uma condição de funcionamento do constitucionalismo democrático. Logo, a intervenção do Judiciário, nesses casos, sanando uma omissão legislativa ou invalidando uma lei inconstitucional, dá-se a favor e não contra a democracia.
\end{abstract}

Em relação à capacidade do Judiciário e seus limites, depreende-se que o Estado possui as funções de legislar, administrar e julgar, cada uma delas exercida por órgãos diferentes, especializados e independentes. Para tanto, observa-se a capacidade institucional, que determina se o órgão está habilitado a produzir melhor decisão em relação à determinada matéria (BARROSO, 2008).

Sendo assim, muitas das decisões e debates promovidos pela Corte têm sido objeto de análise não só por juristas, como também por leigos que acompanham o desenrolar de muitos litígios pela TV Justiça, internet, jornais. Desta feita, Vieira (2008, p. 442, grifo do autor) expõe esse cenário da seguinte forma:

Surpreendente, no entanto, tem sido a atenção que os não especialistas têm dedicado ao Tribunal; a cada habeas corpus polêmico, o Supremo torna-se mais presente na vida das pessoas; a cada julgamento de uma Ação Direita de 
Inconstitucionalidade, pelo plenário do Supremo, acompanhado por milhões de pessoas pela "TV Justiça" ou pela internet, um maior número de brasileiros vai se acostumando ao fato de que questões cruciais de natureza política, moral ou mesmo econômicas são decididas por um tribunal, composto por onze pessoas, para as quais jamais votaram e a partir de uma linguagem de difícil compreensão, para quem não é versado em direito.

Assim, as audiências a portas fechadas que ocorre em tribunais de quase todo o mundo, aqui se julga sob o olhar das câmeras e da população. Alguns não gostam dessa exposição, porém, a visibilidade dada aos julgamentos contribui para a transparência e controle social, bem como para um alcance mais amplo das decisões da Suprema Corte e, em última análise, para a democracia (BARROSO, 2008).

A ampliação da autoridade do Supremo Tribunal Federal reflete uma dinâmica internacional de atuação mais contundente por parte dos tribunais em detrimento do parlamento, que, na maioria das vezes, tem permanecido silente em questões de sua competência. Ao passo que se recorre ao judiciário para dirimir determinadas questões, buscando suprir as lacunas deixadas pelo legislador, amplia ainda mais a crise de autoridade por parte daqueles legitimados e escolhidos pela população para serem seus representantes e defensores de seus interesses.

O fenômeno de centralizar, na Corte, a decisão sobre temas importantes e delicados ocorreu internacionalmente, haja vista o avanço da justiça constitucional em detrimento dos Poderes Legislativo e Executivo, como bem leciona Barroso (2008, p. 1):

Os exemplos são numerosos e inequívocos. No Canadá, a Suprema Corte foi chamada a se manifestar sobre a constitucionalidade de os Estados Unidos fazerem testes com mísseis em solo canadense. Nos Estados Unidos, o último capítulo da eleição presidencial de 2000 foi escrito pela Suprema Corte, no julgamento de Bush v. Gore. Em Israel, a Suprema Corte decidiu sobre a compatibilidade, com a Constituição e com atos internacionais, da construção de um muro na fronteira com o território palestino. A Corte Constitucional da Turquia tem desempenhado um papel vital na preservação de um Estado laico, protegendo-o do avanço do fundamentalismo islâmico. $\mathrm{Na}$ Hungria e na Argentina, planos econômicos de largo alcance tiveram sua validade decidida pelas mais altas Cortes. Na Coréia, a Corte Constitucional restituiu o mandato de um presidente que havia sido destituído por impeachment.

A concentração de poderes na esfera de atuação do Supremo Tribunal Federal tem afetado o equilíbrio da separação dos poderes, bem como vem acumulando, em um único tribunal, as funções de tribunal constitucional, órgão de cúpula do Poder Judiciário e foro privilegiado.

Essa hiperconstitucionalização fez surgir o fenômeno denominado de Supremocracia, termo cunhado por Oscar Vilhena Vieira, admitido como uma singularidade do modelo institucional brasileiro. Como bem assevera Vieira (2008, p. 444-445, grifo do autor) em relação ao duplo sentido do termo:

Em um primeiro sentido, o termo supremocracia
refere-se à autoridade do Supremo em relação às
demais instâncias do judiciário. [...] o Supremo
Tribunal Federal sempre teve uma enorme
dificuldade em impor suas decisões, tomadas no
âmbito do controle difuso de constitucionalidade,
sobre as instâncias judiciais inferiores. [...] com a
adoção da súmula vinculante, completou-se um
ciclo de concentração de poderes nas mãos do
Supremo, voltado a sanar sua incapacidade de
enquadrar juízes e tribunais resistentes às suas
decisões.

Conforme exposto, esse primeiro sentido resulta no reconhecimento da autoridade do Supremo Tribunal Federal em conduzir jurisdicionalmente o Poder Judiciário. Um segundo sentido, atribuído por Vieira, reconhece essa ampliação da autoridade do Supremo em detrimento dos demais Poderes. Assim, leciona que:

[...] com a Constituição de 1988 que o Supremo deslocou-se para o centro de nosso arranjo político. 
Esta posição institucional vem sendo paulatinamente ocupada de forma substantiva, em face a enorme tarefa de guardar tão extensa constituição. [...]o Supremo não apenas vem exercendo a função de órgão de "proteção de regras" constitucionais, face aos potenciais ataques do sistema político, como também vem exercendo, ainda que subsidiariamente, a função de "criação de regras" [...] (VIEIRA, 2008, grifo do autor)

Alguns doutrinadores entendem esse deslocamento do Supremo para o centro político como um avanço, ao passo que, na época da ditadura militar, a Corte não era consultada a respeito de temas polêmicos e importantes, voltando a Constituição de 1988 para um patamar mais próximo do dia-a-dia do povo. Como bem pontua Sarmento (2006, p. 2):

Pela primeira vez na nossa história, os mais relevantes conflitos políticos e sociais estão sendo equacionados a partir da Constituição - do impeachment de um Presidente da República até reformas da Previdência Social; do aborto de feto anencéfalos até o controle de atos de CPI's. Antes, diante de um tema politicamente explosivo, importava saber o que pensavam as Forças Armadas. Agora, muito mais relevante é perscrutar como o STF interpretará as normas constitucionais incidentes sobre o caso.

O fenômeno da Supremocracia tem sido recebido com preocupação por parte de alguns juristas e legisladores, ao passo que parte deles reconhece quão débil o Judiciário se encontrava frente à atuação do Legislativo e Executivo. Neste diapasão, reconhece-se a necessidade de um Poder Judiciário forte para que alcance um equilíbrio entre os três poderes, porém, nasce a preocupação quanto a essa atuação jurisdicional, "[...] é saber se a criatividade judiciária torna o juiz legislador. Se assumindo os juízes papel acentuadamente criativo, a função jurisdicional termina por se igualar à legislativa e os juízes acabam por invadir o domínio do poder Legislativo" (OLIVO, 2000).

A concepção do termo Supremocracia é resultado das escolhas feitas pelo constituinte ao optar por uma Constituição ampla, cidadã, com muitos detalhes e, talvez, uma Constituição ambiciosa, ao elencar, por exemplo, o objetivo fundamental de construir uma sociedade livre, justa e solidária, tomando por base seus fundamentos e princípios. Assim como a maneira escolhida para realizar o controle de constitucionalidade das normas, como também, a presença marcante do constitucionalismo entre os demais ramos do Direito. Desta forma, algumas dessas escolhas ampliaram sobremaneira a atuação do Supremo.

O primeiro dos motivos pelos quais se fala em Supremocracia é a ambição do constituinte de 1988, que buscou legislar a respeito de diversos âmbitos, quais sejam, sociais, econômicos e de outras ordens. A reflexão feita por Vieira (2008, p. 447) acerca desses motivos torna o estudo mais compreensivo, suas ponderações serão expostas a seguir. Sobre essa ambição ele diz:

\begin{abstract}
Este processo, chamado por muitos colegas de constitucionalização do direito, liderado pelo Texto de 1988, criou, no entanto, uma enorme esfera de tensão constitucional e, consequentemente, gerou uma explosão da litigiosidade constitucional. A equação é simples: se tudo é matéria constitucional, o campo de liberdade dado ao corpo político é muito pequeno. Qualquer movimento mais brusco dos administradores ou dos legisladores gera um incidente de inconstitucionalidade, que, por regra, deságua no Supremo.
\end{abstract}

Continuando a análise, Vieira (2008) leciona sobre as competências superlativas, as quais conferem ao Supremo o poder de guardião da Constituição e atribuindo-lhe funções que em outras democracias não se coadunam em um único tribunal, e sim, "estão divididas em pelo menos três tipos de instituições: tribunais constitucionais, foros judiciais especializados (ou simplesmente competências difusas pelo sistema judiciário) e tribunais de recursos de última instância" (VIEIRA, 2008, loc. cit.).

Enquanto tribunal constitucional, o Supremo deve julgar, por meio de ação direta, a 
constitucionalidade de leis e atos normativos. Como bem assevera Vieira (2008, p. 447-448):

\begin{abstract}
A politização desta esfera de jurisdição do Tribunal foi expandida em relação ao período constitucional anterior, na medida em que a legitimidade para a proposição de ações diretas foi conferida a novos atores políticos e sociais, conforme disposto pelo artigo 103 da Constituição Federal, superando a fase em que as chaves de acesso ao controle direto de constitucionalidade pelo Supremo só eram conferidas ao Procurador Geral da República. Essa abertura do Supremo a outros atores políticos tem transformado o Tribunal, em muitas circunstâncias, em uma câmara de revisão de decisões majoritárias, a partir da reclamação daqueles que foram derrotados na arena representativa.
\end{abstract}

Com isso, novos personagens e demandas surgiram, dentre elas a possibilidade de organizações da sociedade civil que atuam como amicus curiae, democratizando ainda mais o acesso ao Supremo Tribunal Federal.

Outra questão que dificulta uma atuação mais célere por parte do Supremo é ter que analisar atos secundários do parlamento ou do executivo, "muitas vezes diretamente ligados à governança interna destes dois poderes. Pior ocorre quando é instado a resolver tais contendas em caráter emergencial" (VIEIRA, 2008).

Alguns casos em que se observa essa atuação Supremocrática são: caso das célulastronco, quotas nas universidades, aborto (anencéfalos), desarmamento, lei de imprensa, direito de greve. Na seara política, cláusula de barreira, fidelidade partidária e mais recentemente $\mathrm{o}$ rito do impeachment. A aparência é de que todas as demandas, para serem eficazmente solucionadas, precisam do aval do Supremo. Pode-se depreender dos casos citados que:

O que ficou claro é que o Supremo não se vê apenas como uma instituição que pode vetar decisões parlamentares claramente inconstitucionais, mas que pode comparar a qualidade constitucional das decisões parlamentares com as soluções que a própria Corte venha a imaginar, substituindo as decisões do parlamento caso entenda que as suas são melhores (VIEIRA, 2008, p. 452).

Alguns constitucionalistas entendem ser bem ponderada a ideia de se fazer uma autocontenção da atuação do Supremo. Um deles, Vieira (2008, p. 458) propõe que:

Ao restringir a sua própria jurisdição, ao se
autoconter, o Supremo estaria, ao mesmo tempo,
reforçando a sua autoridade remanescente e,
indiretamente, fortalecendo as instâncias inferiores,
que passariam, com o tempo, a ser últimas
instâncias nas suas respectivas jurisdições. É
preocupante a posição de subalternidade a que os
tribunais de segunda instância foram relegados no
Brasil, a partir de 1988, quando as suas decisões
passaram a ser invariavelmente objeto de
reapreciação.

Essa seria uma maneira de melhorar ou desafogar o Supremo Tribunal Federal, mesmo que não seja a solução para todas as arestas que surgem ao longo de cada decisão, porém, traria maior integridade e respaldo às decisões proferidas por essa Corte, bem como a participação mais ativa e contundente das instâncias inferiores. Passaria, dessa forma, a dedicar maiores esforços nos julgamentos de grandes temas.

A autocontenção reduz a interferência do Judiciário nos demais Poderes. Vale ressaltar as ponderações de Barroso (2008, p. 6):

(i) evitam aplicar diretamente a Constituição a situações que não estejam no seu âmbito de incidência expressa, aguardando o pronunciamento do legislador ordinário; (ii) utilizam critérios rígidos e conservadores para a declaração de inconstitucionalidade de leis e atos normativos; e (iii) abstêm-se de interferir na definição das políticas públicas.

Do acima exposto, depreende-se que a atuação positiva e contundente do Poder Judiciário, na figura de sua cúpula, tem sido ampliada, tendo em vista a crise na qual se encontram os Poderes Legislativo e Executivo, tanto em relação às denúncias de corrupção, o modo descuidado com que conduzem a política 
brasileira, bem como a efetivação de direitos básicos dos cidadãos brasileiros.

A confiança na Corte tem sido ampliada, a população encontra em seus julgamentos a esperança de promover direitos e garantias, ocupando um espaço de atuação que deveria ser realizado por aqueles que o povo, legitimamente, colocou no poder para tomar as rédeas do país. A omissão e inércia do Legislativo tem sido a grande causa para se falar tanto em Supremocracia. Visto que, mesmo nas questões que os próprios parlamentares poderiam fazer juízo de valor e solucionar, criou-se o hábito de levar ao Supremo para que seja dada a última palavra.

\section{ALGUNS INSTRUMENTOS DE ATUAÇÃO DO SUPREMO TRIBUNAL FEDERAL X SUPREMOCRACIA}

Apesar de, hodiernamente, o Supremo Tribunal Federal, perante a desídia do Poder Legislativo no tocante à necessidade de posicionamento sobre temas relevantíssimos ao ordenamento pátrio, estar sendo invocado para arrematar temáticas que, diretamente, não são de sua alçada, é inabalável o argumento do crescimento constitucional de prerrogativas à Corte Suprema.

Nesse cenário, pois, denotam-se duas situações: a primeira é a necessidade do chamamento do Supremo Tribunal Federal a casos emblemáticos, os quais poderiam ser debatidos e decididos pelo Congresso Nacional, cabendo, em regra, a intervenção da Suprema Corte a posteriori por meio do Controle de Constitucionalidade; a segunda é a atribuição, pela própria Constituição Federal, de prerrogativas, competências e participação do Supremo Tribunal Federal, mormente após as mudanças envidadas pela Reforma do Poder Judiciário, por meio da Emenda Constitucional $\mathrm{n}^{\mathrm{o}} 45$, de 2004.
Nas duas situações acima, o que se observa, escorreita ou equivocadamente, é a expansão dos "poderes" atribuídos ao Supremo Tribunal Federal, a depender da ótica jurídica utilizada. Isso porque a sociedade, diante de toda a incredibilidade em relação ao Congresso Nacional, busca a segurança jurídica, sobretudo em onze ministros escolhidos conforme a reputação ilibada e o notório saber, como determina o art. 101, caput, da Constituição Federal de 1988.

Frente às tais constatações, é indispensável perscrutar algumas disposições constitucionais e/ou legislativas indicadoras de uma maior atuação do Supremo Tribunal Federal, bem como discutir, mesmo que brevemente, alguns temas que repercutiram nacionalmente e chegaram às togas do Supremo Tribunal Federal.

\subsection{As súmulas vinculantes}

Um dos grandes questionamentos acerca da expansão excessiva do Supremo Tribunal Federal paira sobre as súmulas vinculantes. Tal é assim porquanto, por meio das súmulas ora tratadas, há um suposto enrijecimento das convicções dos magistrados em suas decisões judiciais, as quais não podem afrontar o texto normativo vinculante. Nesse sentido, conforme a interpretação, poderia estar havendo ferimento ao princípio do livre convencimento motivado.

Por outro lado, observa-se que o objetivo primordial das súmulas vinculantes é manter a segurança jurídica, tendo em vista que um de seus critérios é a controvérsia judicial. Isto é, procura-se evitar que magistrados, desembargadores e ministros possuam posicionamentos contrários no atinente a um mesmo assunto, com base apenas no seu alvedrio, causando incertezas à sociedade quanto à aplicabilidade jurídica.

Advogando a pertinência das súmulas, Gilmar Ferreira Mendes (2014) discorre que é de 
Kelsen o esclarecimento de que a função criadora do direito dos tribunais, existente em todas as circunstâncias, surge com particular evidência quando um tribunal recebe competência para produzir também normas gerais por meio de decisões com força de precedentes.

Conferir a tal decisão caráter de precedente é tão só um alargamento coerente da função criadora de direito dos tribunais. Se aos tribunais é conferido o poder de criar não só normas individuais, mas também normas jurídicas gerais, estarão eles em concorrência com o órgão legislativo instituído pela Constituição, e isso significará uma descentralização da função legislativa.

Nesse cenário, a instituição da possibilidade de criação das súmulas vinculantes, quando preenchidos os requisitos tabelados pela Constituição Federal, não significa a intervenção do Poder Judiciário na função típica do Poder Legislativo de inovar o ordenamento jurídico. Significa, entretanto, uma extensão inerente ao Poder Judiciário, que há muito se desapegou da erma aplicação da lei ao caso concreto. Por esse diapasão, descabe argumentar a desarmonia dos poderes, conforme dita a Teoria da Separação dos Poderes.

Nesse ínterim, compreende Gilmar Ferreira Mendes (2014) que a súmula do Supremo Tribunal Federal, deitando raízes nos assentos da Casa de Suplicação, nasce com caráter oficial, dotada de perfil indiretamente obrigatório. E, por conta dos recursos, constitui instrumento de autodisciplina do Supremo Tribunal Federal, que somente deverá afastar-se da orientação nela preconizada de forma expressa e fundamentada.

Assim, continua Gilmar Mendes (2014), essas diretrizes aplicam-se também à súmula vinculante consagrada na Emenda n ${ }^{\circ} 45 / 2004$. É evidente, porém, que a súmula vinculante, como o próprio nome indica, terá o condão de vincular diretamente os órgãos judiciais e os órgãos da
Administração Pública, abrindo a possibilidade de que qualquer interessado faça valer a orientação do Supremo, não mediante simples interposição de recurso, mas por meio de apresentação de uma reclamação por descumprimento de decisão judicial.

\subsubsection{Previsão constitucional e legal}

As súmulas vinculantes estão previstas no art. 103-A, da Constituição Federal de 1988, sendo, como já pontuado, uma inovação empreendida pela Emenda Constitucional no 45, de 30 de dezembro de 2004. Ademais, há a previsão legislativa das aludidas súmulas na lei

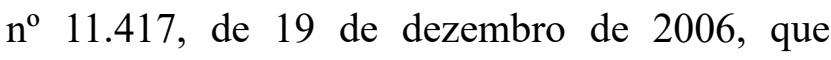
regulamenta a previsão constitucional ora ventilada.

Assim, segundo o $\S 1^{\circ}$ do art. 103-A da Constituição Federal atual, a súmula vinculante terá por objetivo a validade, a interpretação e a eficácia de normas determinadas, acerca das quais haja controvérsia atual entre órgãos judiciários ou entre esses e a administração pública que acarrete grave insegurança jurídica e relevante multiplicação de processos sobre questão idêntica.

Como já alertado em linhas anteriores, um dos requisitos para aprovação das súmulas vinculantes é a controvérsia entre órgãos judiciais ou entre esses e a administração pública. Ensina Gilmar Ferreira Mendes (2014) que essa controvérsia se refere à preexistência de reiteradas decisões sobre matéria constitucional. Exige-se aqui que a matéria a ser versada na súmula tenha sido objeto de debate e discussão no Supremo Tribunal Federal. Busca-se obter a maturação da questão controvertida com a reiteração de decisões.

Veda-se, desse modo, a possibilidade da edição de uma súmula vinculante com fundamento em decisão judicial isolada, o que afasta a arbitrariedade da Suprema Corte. É 
necessário, assim, que ela reflita uma jurisprudência do Tribunal, ou seja, reiterados julgados no mesmo sentido, é dizer, com a mesma interpretação. A súmula vinculante, ao contrário do que ocorre no processo objetivo, como foi visto, decorre de decisões tomadas, em princípio, em casos concretos, no modelo incidental, no qual também existe, não raras vezes, reclamo por solução geral.

Outro requisito essencial é o quórum de aprovação, o qual deve ser de $2 / 3$ (dois terços) dos membros do Supremo Tribunal Federal, segundo dispõe o art. 103-A, caput, da Constituição Federal. Dessa forma, são suficientes oito ministros para que a súmula tenha efeito vinculante. Frise-se, outrossim, que a proposta de aprovação, revisão ou cancelamento de súmula vinculante pode dar-se ex officio pelo próprio Supremo Tribunal Federal, bem como por provocação dos mesmos legitimados para a propositura da Ação de Direta de Inconstitucionalidade, arrolados no art. 103, do Texto Magno de 1988.

São estes os legitimados não só para a ADI, mas também para propor a aprovação, revisão e cancelamento das súmulas vinculantes: o Presidente da República; a Mesa do Senado Federal; a Mesa da Câmara dos Deputados; a Mesa de Assembleia Legislativa ou da Câmara Legislativa do Distrito Federal; o Governador de Estado ou do Distrito Federal; o ProcuradorGeral da República; o Conselho Federal da Ordem dos Advogados do Brasil; partido político com representação no Congresso Nacional; e confederação sindical ou entidade de classe de âmbito nacional.

Preconiza o $\S 3^{\circ}$, do art. 103-A, da CF/88, que o ato administrativo ou decisão judicial que contrariar a súmula aplicável ou que indevidamente a aplicar, caberá reclamação ao Supremo Tribunal Federal que, julgando-a procedente, anulará o ato administrativo ou cassará a decisão judicial reclamada, e determinará que outra seja proferida com ou sem a aplicação da súmula, conforme o caso.

Arremata, por fim, Gilmar Ferreira Mendes (2014) que essa reclamação constitucional está prevista no art. 102, I, l, da Carta de 1988, para preservar a competência e garantir a autoridade das decisões do Supremo Tribunal Federal. O modelo constitucional adotado consagra a admissibilidade de reclamação contra ato da Administração em desconformidade com a súmula. E, na certa, essa é a grande inovação do sistema, uma vez que a reclamação contra atos judiciais contrários à orientação com força vinculante já era largamente praticada. É certo que também essa reclamação estava limitada às decisões dotadas de efeito vinculante nos processos objetivos.

\subsection{O controle de constitucionalidade e a união homoafetiva}

\subsubsection{O Controle de Constitucionalidade}

Outro ponto imprescindível a ser analisado no cenário da suposta elasticidade do poder do Supremo Tribunal Federal é a permissão constitucional de o Poder Judiciário, representado pelo STF, controlar as condutas legislativas por meio das Ações Diretas Constitucionais (Ação Direta de Inconstitucionalidade por Ação e Omissão, Ação Declaratória de Constitucionalidade, Ação Interventiva e Arguição de Descumprimento de Preceito Fundamental).

O Controle de Constitucionalidade consiste no confronto de leis ou atos normativos com a Constituição Federal, verificando se aqueles são compatíveis com o Texto Maior. Nesse diapasão, são carreados inúmeros critérios para o processo em alusão, ilustrativamente, os procedimentos constitucionais para elaboração de uma lei complementar, que, ao serem desprestigiados, desaguam na inconstitucionalidade formal. 
O insigne Mauro Cappelletti (1992) disserta que é, exatamente, na garantia de uma superior legalidade que o Controle Judicial de Constitucionalidade das leis encontra sua razão de ser: e trata-se de uma garantia que, por muitos, já é considerada como um importante, se não necessário, coroamento do Estado de direito e que, contraposta à concepção do Estado absoluto, representa um dos valores mais preciosos do pensamento jurídico e político contemporâneo. E complementando as razões pelas quais há a necessidade do Controle ora tratado, discorre Dirley da Cunha Jr. (2010):

Como já sublinhado, a supremacia da Constituição enquanto princípio jurídico que atribui à Constituição uma forca subordinante e a eleva à condição de legitimidade e validade de todas as normas jurídicas positivadas em um dado Estado - e a base de sustentação do próprio Estado Democrático de Direito, seja porque assegura o respeito à ordem jurídica, seja porque proporciona a efetivação dos valores sociais. Mas essa supremacia constitucional restaria comprometida se não existisse um sistema que pudesse garanti-la e, em consequência, manter a superioridade e força normativa da Constituição, afastando toda e qualquer antinomia que venha agredir os preceitos constitucionais. É nesse contexto que avulta a importância do controle de constitucionalidade como um mecanismo de garantia da supremacia das normas constitucionais delineado pelo próprio texto constitucional (p. 39).

Deveras, o Controle de Constitucionalidade, como afirmado por Mauro Cappelletti e Dirley da Cunha Júnior, representa, hodiernamente, um combate às arbitrariedades ditadas pelo próprio Estado, vez que este encontra limites à sua atuação na Constituição Federal. Por isso, embora se atribua competência constitucional ao Poder Legislativo de inovar juridicamente no ordenamento pátrio, possui o mesmo status o plexo de critérios a serem respeitados para a elaboração de normas.

E, ainda, é do mesmo plano, isto é, constitucional, as normas para o sistema de compatibilidade das leis frente à Lei Maior, conforme se depreende dos arts. 102, I, $a, \S 1^{\circ}$, e 103. Por tais motivos, não encontra razão a argumentação segundo a qual o Controle de Constitucionalidade representaria uma superposição do Poder Judiciário, especialmente o Supremo Tribunal Federal, em relação aos Poderes Executivo e Legislativo.

Decorre o Controle de Constitucionalidade do princípio da Supremacia não do Supremo Tribunal Federal, mas propriamente da Constituição. Esta, como instituidora das principais diretrizes do Estado Democrático de Direito (como é o caso do Brasil), precisa estar acima de qualquer feitura legislativa no país, devendo qualquer violação a ela ser considerada nula.

Corroborando o entendimento acima, Gilmar Ferreira Mendes (2014) defende, em seu curso, que o conflito de leis com a Constituição encontrará solução na prevalência desta, justamente por ser a Carta Magna produto do poder constituinte originário, ela própria elevando-se à condição de obra suprema, que inicia o ordenamento jurídico, impondo-se, por isso, ao diploma inferior com ela inconciliável. De acordo com a doutrina clássica, por isso mesmo, o ato contrário à Constituição sofre de nulidade absoluta.

\subsubsection{A união homoafetiva pelo Supremo}

Tribunal Federal

Em virtude do Controle de Constitucionalidade, é possível realizar alguns apontamentos no respeitante à competência do Supremo Tribunal Federal. Isso porque a sistemática de compatibilidade das leis com a Constituição permite que a Suprema Corte brasileira discuta temáticas relevantíssimas ao cenário político, social e jurídico. Destarte, em debates de repercussão nacional, o STF acaba julgando processos advindos principalmente das Ações Diretas, sendo o único, ou o último 
Tribunal com a competência de analisar o caso posto. Derivam daí, pois, as críticas que efervescem a concepção da Supremocracia.

Cabe aqui expor um dos entendimentos, de grande repercussão, do Supremo Tribunal Federal, o qual fora provocado, especificamente, por uma ação de Arguição de Descumprimento de Preceito Fundamental - ADPF. Trata-se da ADPF 132, tendo como relator o Min. Ayres Britto, e figurando no polo ativo o governador do estado do Rio de Janeiro à época. A aludida ação versava sobre $\mathrm{o}$ reconhecimento da união homoafetiva como entidade familiar juridicamente tutelada pelo Estado. Senão vejase parcialmente a ementa do acórdão:

O sexo das pessoas, salvo disposição constitucional expressa ou implícita em sentido contrário, não se presta como fator de desigualação jurídica. Proibição de preconceito, à luz do inciso IV do art. $3^{\circ}$ da Constituição Federal, por colidir frontalmente com o objetivo constitucional de "promover o bem de todos". Silêncio normativo da Carta Magna a respeito do concreto uso do sexo dos indivíduos como saque da kelseniana "norma geral negativa", segundo a qual "o que não estiver juridicamente proibido, ou obrigado, está juridicamente permitido". Reconhecimento do direito à preferência sexual como direta emanação do princípio da "dignidade da pessoa humana": direito à autoestima no mais elevado ponto da consciência do indivíduo. Direito à busca da felicidade. Salto normativo da proibição do preconceito para a proclamação do direito à liberdade sexual. O concreto uso da sexualidade faz parte da autonomia da vontade das pessoas naturais. Empírico uso da sexualidade nos planos da intimidade e da privacidade constitucionalmente tuteladas. Autonomia da vontade. Cláusula pétrea.

Diante disso, percebe-se a magnitude da participação do Supremo Tribunal Federal no presente julgado, uma vez que, recebendo a ação, pôs-se a verificar a elasticidade do conceito de entidade familiar para reconhecer como famílias o convívio de fato dos casais homoafetivos. Nesse sentido, a decisão prolatada pelo STF repercutiu indubitavelmente não somente na processualística jurídica, mas também nas relações sociais e, especialmente, privadas. Até porque Direito e sociedade devem andar de "mãos dadas".

No presente caso, notou-se uma maciça participação de grupos relacionados, direta ou indiretamente, à temática da homoafetividade e do Direito das Famílias, como Conectas Direitos Humanos, Grupo Gay da Bahia - GGB, Instituto de Bioética, Direitos Humanos e Gênero ANIS, Instituto Brasileiro de Direito de Família - IBFAM etc. Todas essas representações ingressaram como amicus curiae ("Amigo da Corte") na ADPF 132.

Em observação ao voto do Min. Relator Ayres Britto, este discorre, já adentrando ao mérito, que dá ao art. 1.723 do Código Civil interpretação conforme à Constituição para dele excluir qualquer significado que impeça o reconhecimento da união contínua, pública $\mathrm{e}$ duradoura entre pessoas do mesmo sexo como "entidade familiar", entendida esta como sinônimo perfeito de "família". Reconhecimento que é de ser feito segundo as mesmas regras e com as mesmas consequências da união estável heteroafetiva.

Acompanhando o voto do Min. Relator, o Min. Luiz Fux escalpela que o que faz uma família é, sobretudo, o amor - não a mera afeição entre os indivíduos, mas o verdadeiro amor familiar, que estabelece relações de afeto, assistência e suporte recíprocos entre os integrantes do grupo. Lembra, ainda, que a família é a comunhão, a existência de um projeto coletivo, permanente e duradouro de vida em comum. E, por fim, sustenta que uma família é a identidade, a certeza de seus integrantes quanto à existência de um vínculo inquebrantável que os une e que os identifica uns perante os outros e cada um deles perante a sociedade. Presentes esses três requisitos, tem-se uma família, incidindo, com isso, a respectiva proteção constitucional.

$$
\text { Enfim, a ADPF } 132 \text { fora julgada }
$$


procedente pelo Supremo Tribunal Federal, o qual reconheceu a união homoafetiva como uma entidade familiar, e, assim, merecendo proteção estatal. Desse modo, o que é cristalino observar não é a suposta supremacia do STF, mas, relevantemente, a atuação dessa Corte de Justiça que salvaguardou, no caso exposto, a Dignidade da Pessoa Humana dos homossexuais. Assim sendo, o STF somente julgou, conforme sua competência constitucional, um caso que deveria ter sido regulamentado pelo Poder Legislativo mediante os avanços sociais.

\section{CONCLUSÃO}

O surgimento do Estado evidencia-se pela necessidade da paz social, a qual deve estar lastreada legitimamente pelos meios democráticos, isto é, o povo concede parcela de sua liberdade ao ente estatal e, concomitantemente, é o destinatário das benesses governamentais. Nesse sentido, ao lado dos outros dois elementos essenciais, território e povo, o poder é o instrumento de atuação por meio do qual o Estado organiza a estrutura da sociedade.

Por isso, fala-se em poder político, o qual corresponde à soberania do Estado. Esta, como visto, pode ser compreendida sob dois ângulos: o externo, significando a posição do país no cenário internacional, e o interno, aludindo às relações internas com outros poderes delimitados por um feixe de prerrogativas maior, que é o poder estatal.

Brevemente, viu-se, após o conceito e o posicionamento doutrinário quanto ao poder, a historicidade da Teoria da Tripartição do Poder, a qual se iniciou com os estudos de Platão e Aristóteles na Antiguidade e se desenvolveu, ganhando robustez, com John Locke e Montesquieu. Ademais, demonstrou-se, ao se caracterizar o poder como uno, indivisível e indelegável, que o termo "Tripartição" é impróprio, tratando-se, na realidade, de uma divisão de funções estatais.

Nesse cenário, surge a problemática da violação à separação dos poderes, tendo em vista que cada órgão exerce tipicamente sua função, e um embaraço nesse sistema poderia desaguar numa interferência sem previsão constitucional. Desse modo, fala-se em Supremocracia como sendo uma exacerbação do Poder Judiciário, representado, nesse caso, pelo Supremo Tribunal Federal, o qual supostamente interfere nas funções típicas do Poder Legislativo.

Todavia, o que se visualiza, hodiernamente, é uma inércia do Poder Legislativo, o qual consagra violações aos Direitos Fundamentais. Isso porque, ilustrativamente, ao não regulamentar instrumentos de efetivação de um direito social, estar-se-á obstaculizando o exercício da prerrogativa de índole de segunda geração.

Perante tais lacunas pelas "moras legislativas", o STF, por meio de instrumentos assegurados constitucionalmente, como é o caso das súmulas vinculantes e da previsão do Controle de Constitucionalidade, elabora mecanismos que concretizem a Dignidade da Pessoa Humana. A exequibilidade desses instrumentos pôde ser sentida na verificação, por exemplo, do julgamento da ADPF 132, na qual se discutiu a extensão do conceito de família. Enfim, o que se infere é a atuação da Corte Suprema em prol da Lei Fundamental. 


\section{REFERÊNCIAS}

AZAMBUJA, Darcy. Teoria Geral do Estado. 41. ed. São Paulo: Editora Globo, 2000.

BARROSO, Luiz Roberto. Judicialização, Ativismo Judicial e Legitimidade Democrática. Disponível em: <http://www.migalhas.com.br/arquivo_artigo/art20090130-01.pdf >. Acessado em: 08 mar. 2016.

BONAVIDES, Paulo. Curso de Direito Constitucional. 9. ed. rev. ampl. e atual. São Paulo: Malheiros, 2000.

BRASIL, Constituição da República Federativa do Brasil. Disponível em: $<$ http://www.planalto.gov.br/ccivil_03/Constituicao/Constituicao.htm>. Acesso em: 07 mar. 2016.

. Lei $n^{\circ}$ 11.417, de 19 de dezembro de 2006. Regulamenta o art. 103-A da Constituição Federal e altera a Lei no 9.784, de 29 de janeiro de 1999, disciplinando a edição, a revisão e o cancelamento de enunciado de súmula vinculante pelo Supremo Tribunal Federal, e dá outras providências. Disponível em: $<\quad$ http://www.planalto.gov.br/ccivil_03/_ato20042006/2006/lei/111417.htm>. Acesso em 09 de mar. 2016.

. Supremo Tribunal Federal. Direito de família. Arguição de Descumprimento de Preceito Fundamental. Reconhecimento da união homoafetiva como instituto jurídico. Arguição de Descumprimento de Preceito Fundamental 132. Encampação dos fundamentos da ADPF n ${ }^{\circ} 132-R J$ pela ADI no 4.277-DF, Brasília, mai. de 1998.

CAPPELlETTI, Mauro. O Controle Judicial de Constitucionalidade das Leis no Direito Comparado. 2. ed. Tradução Aroldo Plinio Goncalves. Porto Alegre: Sergio Antonio Fabris Editor, 1992.

JÚNIOR, Dirley da Cunha. Controle de Constitucionalidade: teoria e prática. 4. ed. rev. e ampl. Bahia: JusPodivm, 2010.

LOCKE, John. Segundo Tratado sobre o Governo Civil. Tradução Magda Lopes e Marisa Lobo da Costa. São Paulo: Editora Vozes, 1998.

MENDES, Gilmar Ferreira; BRANCO, Paulo Gustavo Gonet. Curso de direito constitucional. 9. ed. rev. e atual. São Paulo: Saraiva, 2014.

MONTESQUIEU. Do Espirito das leis. Tradução Jean Melville. Editora Martin Claret: São Paulo, 2007.

OLIVO, Luís Carlos Cancellier de. Juizes legisladores: o controle de constitucionalidade das leis como forma de exercício do direito judiciário. Disponível em: $<$ https://periodicos.ufsc.br/index.php/sequencia/article/viewFile/15417/13990>. Acessado em: 08 mar. 2016.

PLATÃO. República. Introdução, tradução e notas de Maria Helena da Rocha Pereira. Lisboa: 
Fundação Calouste Guibenkian, 2004.

SARMENTO, Daniel. Ubiqüidade Constitucional: os dois lados da moeda. Revista de Direito do Estado, $\quad$ v. 2006.2 Disponível em: $<$ https://fabioshecaira.wikispaces.com/file/view/ART.+Sarmento+- Ubiquidade+Constitucional.pdf $>$. Acessado em: 08 mar. 2016.

SILVA, José Afonso da. Curso de Direito Constitucional Positivo. 37. ed. São Paulo: Malheiros, 2014.

VERISSIMO, Marcos Paulo. A constituição de 1988, vinte anos depois: Suprema corte e ativismo judicial “à brasileira”. Revista de Direito GV, São Paulo, 4 [2], p.407-440, jul-dez 2008. Disponível em: $\quad<$ http://www.scielo.br/scielo.php?script=sci_arttext\&pid=S1808-24322008000200004>. Acessado em: 09 mar. 2016.

VIEIRA, Oscar Vilhena. Império da Lei ou da Corte? Revista da USP, Dossiê Judiciário, 21, MarMai, 1994, pp. 70-77. Disponível em: <http://www.revistas.usp.br/revusp/article/view/26937>. Acessado em: 07 mar. 2016.

- Supremocracia. Revista de Direito GV, São Paulo, 4 [2], p.441-464, jul-dez 2008. Disponível em: <http://www.scielo.br/pdf/rdgv/v4n2/a05v4n2.pdf>. Acessado em: 07 mar. 2016.

Recebido em: 10/03/2016

Aceito em: 04/07/2016 